\title{
Prevalence of Respiratory Morbidity among Shopkeepers in the vicinity of a National Highway, Bangalore
}

\begin{abstract}
:
Background: Studies done in the West have shown adverse interaction between highway pollutants on cardio pulmonary health of the people working or residing close to the highways. Therefore a study was undertaken to document the respiratory morbidity among shopkeepers working in shops situated on national highway $(\mathrm{NH}) 7$, Bangalore. Objective: To study the prevalence of respiratory morbidity among shopkeepers on $\mathrm{NH}$ 7. Methods: Cross sectional study was done among 121 randomly selected shopkeepers working for more than a year in shops located within 100 meter radius of a junction of $\mathrm{NH}$ 7, Bangalore. A pre-validated questionnaire was administered to the shopkeepers along with measurement of peak expiratory flow rate (PEFR), general physical and systemic examination. Result: Among the study participants, $59.5 \%$ was totally asymptomatic and classified as normal. Others were classified as syndrome of cough (32.2\%), syndrome of breathlessness (31.4\%), syndrome of asthma (12.4\%) and syndrome of atopy (23.1\%). Conclusion: The prevalence of respiratory morbidity and asthma was found to be significantly higher in shopkeepers near the highway than that of currently established data for residents of urban Bangalore. Presence of asthma in shopkeepers had a significant positive correlation with number of hours per day and years of exposure. Large prospective cohort studies could be undertaken to identify the effect of pollutants on the health of shopkeepers. Strengthening existing legislations could help reduce the effect of pollutants on health of shopkeepers working or residing near highways.
\end{abstract} Naveen $\mathrm{R}^{1}$, George K. John ${ }^{2}$,

Key Words: Shopkeepers, respiratory, morbidity, national highway .

Ganesh V'.

1 Associate Professor ; 2 Medical Intern

Department of Community Health, St John's

Medical College, Bangalore 560034. Karnataka, India.

Corresponding Author:

Dr. Naveen Ramesh

Email: drnaveenr@gmail.com

c) 2015 IJOSH All rights reserved.

\section{Introduction}

The relationship between infections and infestations, exposure to air pollution, tobacco smoking and environmental tobacco smoke is complex and confounding.[1] Studies done all over the world indicate that a distinct set of freshly emitted air pollutants from vehicles moving on major highways tend to increase the levels of ultra fine particles, black carbon, oxides of nitrogen and carbon monoxide which adversely affect the cardiac and pulmonary health of people living or spending substantial amounts of time within about 200 meters of highways when compared to people living on busy urban streets. These adverse health outcomes included cardio pulmonary mortality, acute myocardial infarction, asthma, respiratory symptoms, bronchitis, allergy and cancer. [2-8] Studies among children living near major highways have shown that they are at higher risk for development of asthma and reduced lung function. [4,7] Studies also indicate higher prevalence of respiratory symptoms and reactive airway disease among workers engaged in highway construction due to increased amounts of silica and cement dust and diesel exhaust in the surrounding environment.[9]

At present there are very few published studies from India regarding harmful effects of highway pollutants although studies have been carried out comparing hospital admission rates and air pollutant levels in urban areas. [10]

Unlike several countries which have strict regulations concerning housing and business establishments in proximity to major highways, in India majority of shops, especially in the intercity portion of national highways, are located within 100 meters of the highway with clustering seen around major junctions. Shopkeepers near the highway form an "at risk" population, since they spend substantial period of time everyday in their shops situated close to highway. The present study was designed to study the prevalence of respiratory morbidity among 
shopkeepers near the highway in Bangalore.

No documented studies have been done in India to detail the health problems among shopkeepers working within 100 meters radius of the national highway.

\section{Methods}

This was a cross sectional study which included shopkeepers with at least one year experience of working in shops located within a 100 meter radius of $\mathrm{NH} 7$ in Bangalore. The junction formed by meeting of three roads (namely the Hosa road, Doddathogur road and the Electronic city road) onto $\mathrm{NH} 7$ was chosen as the study site. This study included shopkeepers selling goods from a pushcart to those working in concrete shops. Total of 346 shops were listed located within 100 meter radius and by using the simple random number table 121 shops were chosen representing about one third total shops. In the selected shop, one worker who fulfilled the inclusion criteria was selected at random by lottery method. Interviews were conducted after assuring confidentiality of the information and obtaining informed consent from the shopkeeper. Data collected included demographic details, education, type of business, location (floor and distance) of shop, working hours per day, total number of working years and presence or absence of doors which helped to keep the shop enclosed during the working hours. Proximity to the highway was measured using the odometer of a two wheeler used for the study. A pre designed and structured interview schedule was used to collect the data. The interview schedule was designed based on literature review and findings of previous studies done in other countries with additions to collect data on local conditions. The modified International Union Against Tuberculosis and Lung Diseases (IUATLD) questionnaire, pre-validated for use in India, was also used to collect data on respiratory symptoms. Subjects were asked regarding past history of tuberculosis, cardiac symptoms and surgeries. Asthma was diagnosed if the respondent answered affirmatively to wheezing or whistling sound from chest, or chest tightness or breathlessness in morning, and having suffered from asthma, or having an attack of asthma in past 12 months, or using inhaled or oral bronchodilators. Atopy was defined as the presence of two or more of the symptoms of recurrent skin rash, or recurrent episodes of sneezing or coryza, or itchiness in eyes. Standard methodology was used to measure the Peak Expiratory Flow Rate (PEFR) recordings were done using a Mini - Wright Standard range peak airflow meter (EN 13826 Standard EU Scale). General physical examination and systemic examination was done for all study participants. Data was coded and entered in Microsoft Excel and analyzed using SPSS version 16. The demographic data was analyzed using frequencies and mean. Two proportion $z$ test was to determine the significance of association between the morbidity in the present study and a multicenter study. $\mathrm{P}$ value $<0.05$ was considered statistically significant for all analysis.

\section{Results}

This study included 121 shopkeepers with work experience of at least one year and working in shops located within 100 meters radius of the junction on $\mathrm{NH} 7$.

Table 1 shows the distribution of subjects according to age and gender. Majority were in the age group of $20-40$ years. The mean age of shopkeepers was 33.17 years. The percentage of males working in shops $101(83.5 \%)$ was much higher than females $20(16.5 \%)$.

Table 1: Age and Sex Distribution of Study Population

\begin{tabular}{|c|c|c|c|}
\hline Age & Male & Female & Total (\%) \\
\hline $16-25$ & 25 & 4 & $29(23.96)$ \\
\hline 26-35 & 42 & 7 & $49(40.5)$ \\
\hline $36-45$ & 23 & 6 & $29(23.96)$ \\
\hline $46-55$ & 9 & 2 & $11(9.1)$ \\
\hline$>56$ & 2 & 1 & $3(2.5)$ \\
\hline Total (\%) & 101 (83.5) & 20 (16.5) & $121(100)$ \\
\hline
\end{tabular}

We identified 12 varieties of business establishments within a 100 meter radius of the junction. The types of business included - grocery/provision stores 5 (4.1\%), bakery 10 (8.3\%), mechanic/workshop 9 (7.4\%), electrical/ electronic store 10 (8.3\%), phone booth/recharge center 7 (5.8\%), news paper/ Pan stall $6(5 \%)$, vegetable/fruit vendor $22(18.2 \%)$, hotel/ fast food shops $10(8.3 \%)$, ceramic/hardware stores $8(6.6 \%)$, pharmacy 3 $(2.48 \%)$, textile shop $9(11.1 \%)$, hair dresser $2(1.7 \%)$ and others $18(14.9 \%)$.

Table 2, describes the types of shops the study population were working. This description helps to know the probably dose/density of exposure to pollutants.

\section{Table 2: Types of shops}

\begin{tabular}{|c|c|}
\hline Type of shop & Frequency (\%) \\
\hline Pushcart & $29(24.0 \%)$ \\
\hline Open stall & $25(20.07 \%)$ \\
\hline Shutter only & $25(20.07 \%)$ \\
\hline Partially covered & $23(19.0 \%)$ \\
\hline Entry by door & $19(15.6 \%)$ \\
\hline Total (\%) & $101(83.5)$ \\
\hline
\end{tabular}

Most of the shops $110(90.9 \%)$ were located on the ground floor, $10(8.3 \%)$ were in the first floor and one $(0.8 \%)$ was on the second floor.

The duration of time spent by the study subjects or the probable duration of exposure to highway pollutants was more than 10 hours in 91 (75.2\%), between 5-10 hours in 29 (24\%) and less than 5 hours in one $(0.8 \%)$ shopkeepers. The mean working 
hours per day was 10.9 hours.

Similarly $59(48.8 \%)$ of the shopkeepers had worked in the shop for more than 5 years, $36(29.8 \%)$ had worked for $2-5$ years and $26(21.4 \%)$ had worked for less than 2 years. The mean years of working were 6.68 years.

Table 3, is about the approximate distance of the shops from the national highway where study subjects were working.

Table 3: Proximity to highway

\begin{tabular}{|c|c|}
\hline Proximity to highway & Number (\%) \\
\hline$<10$ meters & $38(31.4 \%)$ \\
\hline $10-25$ meters & $26(21.5 \%)$ \\
\hline $25-50$ meters & $31(25.6 \%)$ \\
\hline $50-100$ meters & $26(21.5 \%)$ \\
\hline
\end{tabular}

The distance (in meters) of the shops from the $\mathrm{NH} 7$ was classified as shops within 10 meters, $10-25$ meters, 25-50 meters and $50-100$ meters. Shops within 10 meter radius were the maximum and the frequencies in other class intervals were almost similar. Only $15.7 \%$ of the shops had door at the entry which could be kept closed during the working hours and the remaining shops were either fully or partially open to the surroundings environment.

The Total Exposure Period (T.E.P) is the product of total number of working hours per day per shopkeeper and the number of working years. The mean TEP was 71.04.

The mean normal PEFT for an Indian adult male is $462.12 \pm 100.79$ and for an adult female is $289.30 \pm 60.87$. The mean PEFR, of the study population was $322.56 \mathrm{~L} / \mathrm{min}$. The mean PEFR of male shopkeepers was $333.66 \mathrm{~L} / \mathrm{min}$ compared to $266.50 \mathrm{~L} / \mathrm{min}$ in females. The mean PEFR of shopkeepers classified as asthma group was $205.33 \mathrm{~L} / \mathrm{min}$. Mean PEFR for breathlessness group was $264.21 \mathrm{~L} / \mathrm{min}$ and in the cough group was $255.38 \mathrm{~L} / \mathrm{min}$. Mean PEFR of smokers was $286.49 \mathrm{~L} / \mathrm{min}$. In shopkeepers having shops with partial covering or entry by door the mean PEFR was 346.37 compared to 309.35 in shops open to the surroundings. PEFR did not show much variation with proximity to highway but showed greater fall with increase in the Total Exposure Period. PEFR has been used as an objective measurement of studying the effect of air pollutants on lung function in previous studies.[11,12]

In table 4, the classification based on the health symptoms of the shopkeepers were divided into normal, syndromes of cough, breathlessness as per categories defined by previous studies using the original IUATLD questionnaire.[1,13] As per the IUATLD definitions , 72 (59.5\%) of the total study population did not have any respiratory symptoms and were considered normal; $39(32.2 \%)$ was classified as cough and $38(31.4 \%)$ was classified as breathlessness. These syndromes were not mutually exclusive of each other and had a significant overlap.
Asthma was present in $15(12.4 \%)$ and atopy was prevalent among $28(23.1 \%)$. The questionnaire items relating to asthma in the IUATLD questionnaire has been proven to be a significant predictor of physician diagnosed asthma and positivity on histamine challenge tests in previous studies. [13 -16]

Table 4: Prevalence of respiratory morbidity based on IUATLD questionnaire

\begin{tabular}{|c|c|}
\hline Proximity to highway & Number (\%) \\
\hline Normal & $72(59.5 \%)$ \\
\hline Cough & 39 (32.2\%) \\
\hline Breathlessness & 38 (31.4\%) \\
\hline Asthma & $15(12.4 \%)$ \\
\hline Atopy & $28(23.1 \%)$ \\
\hline
\end{tabular}

Among the study population, $25(20.7 \%)$ had a first degree relative with asthma and $28(23.1 \%)$ had a first degree relative with atopy. Among the asthmatics, $57(47.1 \%)$ had family history of asthma.

In the study population, $37(30.6 \%)$ of the shopkeepers were currently using tobacco in smoke form, $23(19 \%)$ were consuming tobacco in chewable form and $10(8.3 \%)$ used tobacco in both the above mentioned forms. The cooking fuel can be a confounding factors which also has a bearing on cardiorespiratory morbidity and mortality. Among the study population LPG was used in 90 (74.4\%) houses, kerosene in 24 $(19.8 \%)$ and wood in $7(5 \%)$ of the houses.

Other co-morbidities include, $16(13.2 \%)$ of the shopkeepers had wheeze on auscultation, three $(2.5 \%)$ of the population had a history of tuberculosis in the last five years and three $(2.5 \%)$ of the population had history of old myocardial infarction or previous major heart surgery.

\section{Discussion}

Asthma was found to be more in shopkeepers working in open shops (13.7\%) as compared to those in closed shops (5.3\%). Prevalence of asthma increased with increasing number of years spent in the shop, (9.6\%) in shopkeepers working for less than 10 years as compared to $(15.3 \%)$ in shopkeepers working for greater than 10 years. In shopkeepers working in shops less than 50 metres from the highway the prevalence of asthma was $15(12.6 \%)$ which was higher compared to $14(11.5 \%)$ in shopkeepers working more than $50 \mathrm{~m}$ away. Asthma prevalence in shopkeepers working for less than 10 hours was $13(11 \%)$ compared to $20(16.7 \%)$ in shopkeepers working more than 10 hours a day. However, none of these were statistically significant. 
Table 5: Comparison of respiratory morbidity

\begin{tabular}{|c|c|c|c|c|c|c|}
\hline & \multicolumn{2}{|c|}{$\begin{array}{l}\text { Study population } \\
n=121\end{array}$} & \multicolumn{2}{|c|}{$\begin{array}{l}\text { Prevalence } \\
\text { study }^{1} \\
n=17,441\end{array}$} & \multirow[t]{2}{*}{$\begin{array}{l}Z \\
\text { score }\end{array}$} & \multirow[t]{2}{*}{$\begin{array}{l}P \\
\text { value }\end{array}$} \\
\hline & $\mathbf{n}$ & $\%$ & $\mathbf{n}$ & $\%$ & & \\
\hline Cough & 39 & 32.2 & 85 & 4.9 & 41.6 & $<0.01$ \\
\hline Breathlessness & 38 & 31.4 & 576 & 3.3 & 16.8 & $<0.01$ \\
\hline Asthma & 15 & 12.4 & 605 & 3.47 & 5.3 & $<0.01$ \\
\hline Atopy & 28 & 23.1 & 1186 & 6.8 & 7.06 & $<0.01$ \\
\hline $\begin{array}{l}\text { Abnormal } \\
\text { Population }\end{array}$ & 49 & 40.4 & 1796 & 10.3 & 10.8 & $<0.01$ \\
\hline
\end{tabular}

Two proportion $z$ test

The proportion of subjects with cough, breathlessness, asthma and atopy was considerably high in the study population $(32.2 \%$ $, 31.4 \%, 12.4 \%$ and 23.15 respectively) as compared to the reference population( $4.9 \%, 3.3 \%, 3,47 \%$ and $6.8 \%$ respectively) .This difference was statistically significant since $P$ value $<0.01$ at $5 \%$ significance level.

Overall proportion of subjects with abnormality was $10.3 \%$ in the reference study whereas our study shows a significantly $(P<0.01)$ high proportion of abnormal subjects $(40.4 \%)$.

The prevalence of asthma and other respiratory morbidities among the study population of shopkeepers was higher compared to the multicentric study done by Aggarwal et al. [1] looking at the prevalence and risk factors for bronchial asthma in Indian adults. The prevalence of cough, breathlessness, asthma and atopy is significantly higher in the study population compared to the general population as shown in Table 5. The percentage of current smokers is also significantly higher $30.6 \%$ in this study compared to $13.9 \%$ in the general population of urban Bangalore. 1 However, the prevalence rates in the current study is comparable with the prevalence rates of asthma in industrialized western countries where diagnosed asthma (i.e. asthma ever diagnosed by a clinician) in adults is generally reported as 2.7 to $4.0 \%$ in most European countries, $12.0 \%$ in England and $7.1 \%$ in the US. In Australia, the prevalence is rather high (9.5 to $17.9 \%$ ).

PEFR has been used in several studies as an indicator of changes in respiratory function with air pollutant levels both in general population and asthmatics.[11,12] The sensitivity of PEFR measurements compared to spirometry as an indicator of declining lung function is still not clearly established. A study done by Van Der Zee et al showed significant correlation between decrements in morning PEFR with airborne concentrations of several pollutants.[12]

\section{Conclusion}

Although the prevalence of respiratory morbidity is much higher in the current study population compared to general population, previous studies show that a majority of the cough syndrome constituted of current smokers. The prevalence of breathlessness is also not a major indicator of respiratory morbidity alone as breathlessness was also contributed to by heart failure, obesity and various such factors.

The presence of asthma in shopkeepers near the national highway which was significantly higher than that in general urban population was found to be dependent on the total exposure period that is the number of working hours per day and the number of working years.

Based on these findings, the recommendations are as follows:

1. Large prospective cohort studies on people working and/or living in the vicinity of highways can help establish a causal relationship.

2. Trees should be planted along the highways. Trees act as biological filters due to their large leaf areas relative to the ground on which they stand and the physical properties of their surfaces, thus removing large number of airborne particles.

3. Regular air quality monitoring to be carried out especially along major highways and highly polluted urban areas.

4. Improving working hours at shops. Most small businesses have just a few workers working for greater than 10-12 hours a day.

5. Providing temporary shelters for open shops especially open stalls and pushcarts.

6. Educate the shop keepers about the health hazards of exposure to highway pollutants and use of personal protective equipment like masks may be used if affordable and if working in a suitable business.

The study was limited to one junction on the $\mathrm{NH}$ and we were not able to conduct pulmonary function test among the study population.

\section{References}

1. A.N. Aggarwal, K. Chaudhry, S.K. Chhabra, G.A. D'Souza, D. Gupta,S.K. Jindal, S.K. Katiyar, R. Kumar, B. Shah and V.K. Vijayan for Asthma Epidemiology Study Group Prevalence and Risk Factors for Bronchial Asthma in Indian Adults: A Multicentre Study.Indian J Chest Dis Allied Sci 2006; 48: 13-22.

2. Miller KA, Siscovick DS, Sheppard L, Shepherd K, Sullivan JH, Anderson GL, Kaufman JD: Long-term exposure to air pollution and incidence of cardiovascular events in women. The New England Journal of Medicine 2007, 356:447-458.

3. Hoffmann B, Moebus S, Stang A, Beck E, Dragano N, Möhlenkamp S, Schmermund A, Memmesheimer M, Mann K, Erbel R, Jockel KH, Heinz Nixdorf RECALL Study Investigative Group: Residence close to high traffic and prevalence of coronary heart disease. European Heart Journal 2006, 27:2696-2702. 
4. Van Vliet $\mathrm{P}$, Knape $\mathrm{M}$, de Hartog J, Janssen $\mathrm{N}$, Harssema $\mathrm{H}$, Brunekreef $\mathrm{B}$ : Motor vehicle exhaust and chronic respiratory symptoms in children living near freeways. Environmental Research 1997, 74:122-132.

5. Waldron G, Pottle B, Dod J: Asthma and the motorways One district's experience. Journal of Public Health Medicine 1995, 17:85-89.

6. Kim JJ, Smorodinsky S, Lipsett M, Singer BC, Hodgson AT, Ostro B: Traffic-related air pollution near busy roads: The East Bay children's respiratory health study. American Journal of Respiratory and Critical Care Medicine 2004, 170:520-526.

7. Brunekreef $B$, Janssen NA, de Hartog J, Harssema $H$, Knape $M$, van Vliet $P$ : Air pollution from truck traffic and lung function in children living near motorways. Epidemiology 1997, 8:298-303.

8. Janssen $\mathrm{NA}-\mathrm{H}$, Brunekreef $\mathrm{B}$, van Vliet $\mathrm{P}$, Aarts $\mathrm{F}$, Meliefste $K$, Harssema $H$, Fischer $P$ : The relationship between air pollution from heavy traffic and allergic sensitization, bronchial hyperresponsiveness, and respiratory symptoms in Dutch school children. Environmental Health Perspectives 2003, 111:1512-1518.

9. L. Christine Oliver, Heidi Miracle-McMahill, Andrew B. Littman, J. Michael Oakes, Raymond R. Gaita Jr. Respiratory symptoms and lung function in workers in heavy and highway construction: A cross-sectional study American Journal of Industrial Medicine 2001,40,1:73-86.

10. J.N.Pande,Narendra Bhatta,Dilip Biswas,Ravindra M. Pandey,Gautam Ahluwalia,Naveen H. Siddaramaiah,G.C.Khilnani Outdoor Air Pollution and Emergency Room Visits at a Hospital in Delhi. Indian J Chest Dis Allied Sci 2002; 44:13-19.

11. Pekkenen J, Timonen KL, Ruuskanen J, Reponen A, Mirme $A$ : Effects of ultrafine and fine particulates in urban air on peak expiratory flow among children with asthmatic symptoms. Environmental Research 1997, 74:24-33.

12. Van der Zee SC, Hoek G, Boezen HM, Schouten JP, van Wijnen $\mathrm{JH}$, Brunekreef $\mathrm{B}$ : Acute effects of air pollution on respiratory health of 50-70 yr old adults. Eur Respir J.2000; 15:700-709.

13. Bai J, Peat JK, Berry G, Marks GB, Woolcock AJ. Questionnaire items that predict asthma and other respiratory conditions in adults. Chest. 1998;114:1343-1348

14. Torén K, Brisman J, Järvholm B. Asthma and asthma-like symptoms in adults assessed by questionnaires. A literature review.Chest 1993; 104: 600-608.

15. Burney P G J, Laitinen LA, Perdrizet S, et al. Validity and repeatability of the IUATLD (1984) bronchial symptoms questionnaire:an international comparison. Eur Respir J 1989; 2:940-945.
16. Burney $P$ G J, Chinn $S$, Britton $J$ R, Tattersfield A E, Papacosta A O. What symptoms predict the bronchial response to histamine?Evaluation in a community survey of the bronchialsymptoms questionnaire (1984) of the International Union Against Tuberculosis and Lung Disease. Int J Epidemiol 1989; 18: 165-173.

17. Burney P, Malmberg E, Chinn S, Jarvis D, Luczynska C, Lal E. The distribution of total and specific serum IgE in the European Community Respiratory Health Survey. J Allergy Clin Immunol 1997; 99: 314-22.

18. Chinn S, Burney $P$, Jarvis D, Luczynska C. Variation in bronchial responsiveness in the European Community Respiratory Health Survey (ECRHS). Eur Respir J 1997; 10:2495-2501.

19. European Community Respiratory Health Survey.Variations in the prevalence of respiratory symptoms, self reported asthma attacks, and use of asthma medication in the European Community Respiratory Health Survey (ECRHS). Eur Respir J 1996; 9: 687-95.

20. Devereux G, Ayatollahi T, Ward R, Bromly C, Bourke SJ,Stenton SC, et al. Asthma, airways responsiveness and air pollution in two contrasting districts of northern England.Thorax 1996; 51 : 169-74.

21. Peat JK, Haby M, Spijker J, Berry G, Woolcock AJ.Prevalence of asthma in adults in Busselton, Western Australia. BMJ 1992; 305: 1326-9.

22. Doug Brugge, John L Durant, Christine Rioux.Nearhighway pollutants in motor vehicle exhaust: A review of epidemiologic evidence of cardiac and pulmonary health risks, Environmental Health 2007, 6:23.

23. McConnell $R$, Berhane $K$, Yao $L$, Jerrett $M$, Lurmann $F$, Gilliland F, Kunzli N, Gauderman J, Avol E, Thomas D, Peters J: Traffic susceptibility, and childhood asthma. Environmental Health Perspectives 2006, 114:766-772. 